\title{
RISK ANALYSIS FOR THE OCCUPATIONAL HEALTH AND SAFETY ANALYSIS OF SOLID WASTE ORGANIZED STORAGE FACILITIES-BINGÖL EXAMPLE
}

\author{
Mehmet Suddık Baki ${ }^{*}$, Mine Şenel ${ }^{2}$, Bilgin Şenel ${ }^{2}$ \\ ${ }^{I}$ Directorate of Water and Canal Services, Bingöl Governorship, Bingöl, Turkey. \\ ${ }^{2}$ Fethiye Faculty of Business Administration, Muğla Sitkı Koçman University, Muğla, Turkey.
}

\begin{abstract}
Original scientific paper As a result of the studies, in Turkey and the world of work accidents and occupational diseases has emerged as a major issue. Not enough attention to occupational health and safety, lack of occupational health and safety awareness throughout the employees, long working hours, intense work pace, lack of personal protective equipment, inexperience and lack of training/information are the leading causes of occupational accidents.

It has been observed that occupational accidents occur at a high rate due to reasons such as long working hours, intense work tempo, inexperience and lack of education / information among the people working in solid waste landfill facilities. From this point of view, it is aimed to determine the hazards that may be encountered in the storage operations in solid waste facilities and to bring the hazards to an acceptable level as a result of the risk assessment.

In this context the conceptual framework of occupational health and safety at work, health and safety practices of the general procedures of the subject areas of the literature was conducted in Turkey. Then, it is aimed to determine occupational health and safety risks in storage works in solid waste facilities and to determine what kind of measures can be taken against these risks. In this direction, to determine the hazards and risks encountered in solid waste sanitary landfill operations, error types and impact analysis method were used and risk assessment studies were made and solution suggestions were developed.
\end{abstract}

\section{KATI ATIK DÜZENLI DEPOLAMALI TESISLERINDE HATA TÜRÜ ETKILERI ANALIZI YÖNTEMIYLE IŞ SAĞLIĞI VE GÜVENLiĞi AÇISINDAN RISK ANALIZii-BINGÖL ÖRNEĞi}

\section{$\ddot{O}_{z e t}$}

Orijinal bilimsel makale

Yapılan araştırmalar neticesinde, Dünyada ve Türkiye'de iş kazaları ve meslek hastalıkları çok önemli bir sorun olarak karșımıza çıkmaktadır. İs sağlığı ve güvenliğine yeterince önem verilmemesi, çalışanların genelinde iş sağlığı ve güvenliği bilincinin bulunmaması, uzun çalışma saatleri, yoğun iş temposu, kişisel koruyucu kullanmama, tecrübesizlik ve eğitim/bilgi eksikliği, iş kazaların sebeplerin başında gelmektedir.

Katı atık düzenli depolama tesislerinde çalışan kişilerin de uzun çalışma saatleri, yoğun iş temposu, tecrübesizlik ve eğitim/bilgi eksikliği gibi nedenlerden dolayı iş kazalarının yüksek oranda yaşandığı gözlemlenmiştir. Çalışmada bu noktadan hareketle katı atık tesislerinde depolama işlemlerinde karşılaşılabilecek tehlikelerin belirlenerek risk değerlendirmesinin oluşturulması sonucu tehlikelerin kabul edilebilir seviyeye getirilmesi amaçlanmıştır. Bu çalışmada iş sağlığı ve güvenliğinin kavramsal çerçevesini, iş sağlığı ve güvenliğinin genel prosedürlerini Türkiye'deki uygulamalarını konu alan literatür taraması yapılmıştır. Daha sonra ise katı atık tesislerinde depolama işlerinde iş sağlı̆̆ı ve güvenliği risklerinin saptanması ve bu risklere karşı ne tür tedbirler alınabileceğinin belirlenmesi amaçlanmıştır. Bu doğrultuda katı atık düzenli depolama işlemlerinde karşılaşılan tehlike ve riskleri saptamak için hata türleri ve etki analizi yöntemi kullanılıp risk değerlendirmesi çalışması yapılarak çözüm önerileri geliştirilmiştir.

Anahtar Kelimeler: Katı atı, Depolama, Hata türleri ve etki analizi

\section{Giriş}

Günümüz sanayi dünyasındaki ilerlemeler, tarihten bugüne farklılık gösteren ve artan tüketim düşkünlüğü, nüfus artışları, planlı olmayan kentleşme ve doğal olan kaynakların istenmeyen şekilde harcanması gibi nedenler çevresel sisteme zarar vererek negatif sonuçlara neden olmaktadır. Atıklar çevresel kirliliğinin nedenlerinin başında gelmektedir. Atık sorunu planlı olmayan şehir yapılaşması nüfusun artışıyla bir araya gelmesinden ortaya çıkmaktadır. Habitat kaynaklarının yetersiz olması, atıkların doğaya bilinçsiz bir şekilde bırakılması kurtarılamaz doğa kirliliğine neden olmaktadır. Doğal olan kaynaklarda erken tüketme ve kirletme, diğer yönden doğadaki sistemdeki her canlı yaşamı negatif olarak etkilemektedir.

Çeşitli kaynaklardan farklı atık oluşabilmektedir. Atık çeşitlendirmesine göre, katı, evsel olan, inşaatlardan moloz atıklar, endüstri kaynaklı sanayi atığı ve tehlikeli olan kalıntılar gibi sınıflandırmaları olabilmektedir. Ev kaynaklı çıkan atıklar tehlikeli ve doğaya zarar vermeyen atıklar şeklinde olabilmektedir. Yapı işlerinden, evlerdeki yenilemelerden meydana çıkan taşlar, kereste, çelik gibi sonuçlu atıklar inşaat moloz atığı kategorisine girmektedir. Endüstriden çıkan katı atıklar, sanayi ve türlü imalat tesislerinde meydana gelebilen insana ve çevreye zararlı olabilecek tehlikeli türdeki atıklar olmaktadırlar. Sağlık alanlarındaki, klinik ve muayenehane gibi merkezlerdeki

\footnotetext{
* Corresponding author

E-mail address: mesbaki@hotmail.com (M. S. Baki) | ORCID Number : 0000-0001-7276-2045

Received 03 November 2020; Received in revised form 03 December 2020; Accepted 03 December 2020
} 
atıklar ilaçlar, tıbbi malzemeler, operasyon ve tedaviler esnasında çıkabilen sonuçlar olarak, tıbbi atıklar şeklinde değerlendirilmektedir.

İş kazaları ve meslek kaynaklı hastalıklara yakalanmamak, İş Sağlığı ve Güvenliği (İSG) gerçeklerine dikkat etmek ve uygulamakla mümkün olmaktadır. Dizayn edilen ve inşa edilmesi planlanan çalışma alanının çalışanlar üzerindeki negatif etkilerinin bulunmaması için değişik üretimsel etkinlikler planlaması İş Sağlığı ve Güvenliği kültüründeki asıl amacı oluşturmaktadır [1].

İşyerlerinde türlü sıkıntılar zararlı olmayan oranlara çekilebilir veya tamamı ortadan kaldırılarak asıl hedeflenen kabul edilebilir risk seviyesine getirilir. $\mathrm{Bu}$ amaçla iş mahallindeki risk değerlendirme çalışmaları doğrultusunda sağlık için aykırılıkların ve ters hususların ele alınması, çalışanların iş bölgelerinde koşullarının iyi olması, etkin eğitim sürekliliği ve tüm bunların bir denge içerisinde olması gereklidir.

İş Sağlığı ve Güvenliği aşağıdaki kavramlara dayanmaktadır:

- Tehlike tanımlama: Bir örgünün var olduğunu tanıma süreci; insan yaralanması veya kötü sağlık açısından zarar verme potansiyeli olan kaynak veya durum.

- Risk değerlendirmesi: Tehlikeden kaynaklanan riski değerlendirme süreci; tehlikeli bir olayın veya maruz kalma olasılığının ve maruz kalmanın neden olabileceği yaralanma veya kötü sağl1k şiddetinin birleşimi.

- Uygulanabilir kontrollerin belirlenmesi: Riski kabul edilebilir bir düzeye getirmek veya azaltmak için ilgili önlemler. Önlemler, kontrol önlemleri hiyerarşisine dayanmaktadır.

Sağlık sistemine ulaşmak ve etkin iş güvenliği için, kuruluşların bunları daha anlamlı bir şekilde ele almaları hayati önem taşımaktadır. Yukarıdaki üç husus, iyi bir İş Sağlığı ve Güvenliği sisteminin uygulanması için giderek daha önemli hale gelmektedir ve altyapı olmaksızın, tüm sistem kesinlikle başarısız olacaktır. Onlar, teoride, "plan" aşamasının bir parçası olarak kabul edilir, ancak denetçilerin ve danışmanların çoğu, sistemi bir bütün olarak tasarlamadan önce bu konuların ele alınması gerektiği konusunda hemfikirdir.

OHSAS (Occupational Healthand Safety Assesment Series) 18001 İş Sağlığı ve Güvenliği Standardı, PUKÖ döngüsü (Planla-Uygula-Kontrol Et-Önlem Al) adı verilen bir araç yönetimi yaklaşımı kullanır. PDCA (PlanDo-Check-Act) bir kuruluşun üst yönetim liderliği ve sistem güvenlik yönetimine bağlılığı temel alarak sağlık ve güvenlik politikalarını oluşturmasına, uygulamasına ve sürdürmesine olanak tanıyan, devam eden bir süreçtir.

Planla: İşletmenin İş sağlığı ve güvenliği açısından en doğru hedeflere ulaşması için planlar hazırlamak.

Uygula: Süreci uygulayın.

Kontrol et: İş Sağlığı ve Güvenliği politikası, hedefleri, yasal ve onun gibi başka politikalara göre performansın izlenmesi ve ölçülmesini sağlayın.

Önlem al: İş Sağlığı ve Güvenliği çalışmalarını devamlı yükseltmek için harekete geçin.

Standart herhangi bir kuruluşa veya sadece bir kısmına dağıtılabilir. En iyi sonuçlar, tüm kuruluşun aynı sistem üzerinde çalışmasına ve İş Sağlığı ve Güvenliğ politikasının kuruluşun diğer yönetim sistemlerine ve kültürüne entegre edilmesi ile elde edilir.
Planla

Sürecin planlama aşaması kuruluşun şunları yapmasını gerektirir:

- Bir İş Sağlığı ve Güvenliği politikası oluşturmak.

- Tehlikelerin tanımlanması, risk değerlendirmesi ve kontrollerin belirlenmesi için plan yapın.

- İlgili yasal gereklilikleri belirlemek.

- Acil durumlar ve yanıtlar için plan yapın.

- Değişimi etkin bir şekilde yönetin.

- Performans ölçme, izleme ve iyileştirme prosedürleri geliştirin

- Güvenlik ekipmanının uygun kullanımını sağlamak ve sağlamak.

- Bir İş Sağlığı ve Güvenliği kültürünü tanıtmak ve kuruluşun güvenlik beyanı, politikaları ve hedeflerinin önemini belirlemek için eğitim.

- Çalışanlara danışın ve iletişim kurun.

İlk olarak, yeni sistemi desteklemeye ve sürekli ilerlemeye güven duymak için yönetime danışılmalıdır. Daha sonra işgücüne danışılmalıdır. Alt düzey çalışanların yeni sistem hakkında değerli bilgi, fikir ve görüşlere sahip olması muhtemeldir. Ondan en çok etkilenecekleri için, değişim ihtiyacına inanmalarını ve anlamalarını sağlamak mantıklıdır. Bu hususların farkına varmazsanız, kuruluş genelinde çok fazla direnç ortaya çıkabilir ve bu nedenle yalnızca çalışması pratik olmayan bir sistem ortaya çıkabilir.

Uygulama aşaması bu sürecin en kolay kısmı olmalıdır. Planlama aşaması doğru şekilde yapılırsa, bu sadece oluşturulan dokümantasyon ve prosedürleri takip etme meselesidir. Uygulama liderliğini sağlamak için, sürecin her öğesinin bir sahibi veya sistemle ilgilenen bir kişi olması gerekirken, üst düzey bir yönetici yeni sistemden sorumlu olmalıdır. Bu, kuruluşunuz için uygun yapıyı sağlar ve riski etkili bir şekilde en aza indirir.

Uygulamay1, bir bütün olarak ele almak için sistemi belirli elemanlara ayırarak başlatmanız önerilir. Mantıksal bir sırada belirli öğelere odaklanmak, tüm sistemin verimli çalışması için sağlam bir temel oluşturur. Sağlık ve güvenliğin bir diğer önemli yönü de çalışanların becerilerine uygun işleri yapmalarını sağlamaktır. Tüm personel gruplarını ve onların gerekli becerilerini gösteren bir matris oluşturulmalıdır. Eğitim ve her birinin beceri durumu. $\mathrm{Bu}$ resmi prosedürler kuruluşunuzda gerekli bilinci aşılamalıdır.

Kontrol et

PUKÖ döngüsünün üçüncü adımı aşağıdakilerden oluşur:

- İç denetimlerin yapılması.

- Yasal uygunluğun değerlendirilmesi.

- Uygunsuzlukları belirleme ve bunlara hitap etme.

- Olayların ve arızi verilerin kapsamlı analizi.

- Performans ölçümü ve izleme

İç denetimlerin periyodik olarak yapılmaması büyük olasılıkla sistemin bir bütün olarak bozulmasına neden olur. Çoğu zaman kontrolün olmadığı yerlerde, risklerin özellikle hızlı bir şekilde ortaya çıkma eğilimi vardır.

Herhangi bir uygunsuzluk, oluşturulan düzeltici önlemler kullanılarak anında ele alınmalıdır. En etkili ve sağlam sistemler, bu sürecin her zaman sorunsuz bir şekilde çalışmasını sağlar. $\mathrm{Bu}$, bu işlemin performansının da ölçülmesi gerektiği anlamına gelir. 
Organizasyonun düşünmesi gereken sadece uygunsuzluklar değildir. Kuruluşun potansiyel acil durumları tanımlaması ve müdahale ile ilgili prosedürler geliştirmesi çok önemlidir, buna önleyici eylem denir.

Son adım çalışma ortamının gözetimi ve denetimi ile elde edilen verilere uygun iyileştirilmelerin yapılmasıdır, bu da sürekli iyileştirme sürecinin hayati bir parçasıdır. Bu nedenle standardın kendisi gerekli incelemede hangi hususlara dikkat edilmesini kendisi özetler.

Yönetimin gözden geçirilmesi üst yönetim tarafindan yürütülür ve sistemin uygunluğunun, yeterliliğinin ve etkinliğinin gözden geçirilmesidir. Ayrıca iyileştirme firsatları, İş Sağlığı ve Güvenliği politikası ve İş Sağlığı ve Güvenliği hedeflerinin değiştirilmesi ihtiyacının değerlendirilmesini de içermelidir. Değişiklikler gereklidir, üst yönetim de uygulama için gerekli kaynakları sağlamalıdır. Kaynak sağlamak, yeni sağlık ve güvenlik sistemine bağl1lık göstermenin bir yoludur. İş yaparken meydana gelen yaralanmalar, meslek kaynaklı hastalıklar çalışma hayatındaki en çok karşılaşılan sorunlardandır.

Çoğunlukla küçük ve orta ölçekli firmaların yoğunlukta olduğu ülkemizde çalışma şartlarının uygun hale getirilmesi, eğitim, denetleme sistemlerinde beklenen düzeyde meydana çıkmaması, iş kazaları üzerinde yükselten bir etkiye sahiptir. Kayıt dışı işçilerin uğradığı kaza vakaları kayıt altına alınmadığından, kaza verilerinin doğruluğu tartışılmaktadır.İş kazaları ilgili araştırmalara müsaade etmemekte, hatta birakmamaktadır.

\section{Hata Türü ve Etkileri Analizi (HTEA)}

Hasar, bir ürün veya elemanın, belirlenen ömrü boyunca fonksiyonunu (kendisinden beklenen amacı ve performans1) yerine getirememesidir. Başka bir deyişle, işe yaramama durumudur ve müşteri memnuniyetsizliğinin başlıca nedenidir. Hasarın sebebi olan hata ise tatmin etmeyen performanstır. Hata Türü; hatanın kendini belli etme şekli; bir kişi veya ekipmanın görevini yapmadığ durum olarak kabul edilebilir. Hata etkisi, nedenin sonucu; bir hata oluştuğunda sistemi ya da müşteriyi nasıl etkileyeceğidir. Hata sebebi ise hatanın oluşmasını sağlayan olumsuz durumdur. Özetle HTEA, sistemli olarak konan bir erken tanıdır.

Süreç, ürün veya hizmet ve müşteri ihtiyaçları hakkında çeşitli bilgilere sahip, çapraz işlevli bir ekip oluşturun. Genellikle dahil edilen işlevler şunlardır: tasarım, üretim, kalite, test, güvenilirlik, bakım, satın alma (ve tedarikçiler), satış, pazarlama (ve müşteriler) ve müşteri hizmetleri.

HTEA'nın kapsamını belirleyin. Kavram, sistem, tasarım, süreç veya hizmet için mi? Sınırlar nelerdir? $\mathrm{Ne}$ kadar ayrıntılı olmalıyız? Kapsamı tanımlamak ve her ekip üyesinin bunu ayrıntılı olarak anladığından emin olmak için akış şemalarını kullanın.

Kapsamınızın işlevlerini tanımlayın. "Bu sistemin, tasarımın, sürecin veya hizmetin amac1 nedir? Müşterilerimiz bunun ne yapmasını bekliyor?" Bir fiilin ardından bir isim verin. Genellikle kapsam ayrı alt sistemlere, öğelere, parçalara, montajlara veya işlem adımlarına bölünür ve her birinin işlevini tanımlar.
Her işlev için hatanın oluşabileceği tüm yolları tanımlayın. Bunlar potansiyel hata türleridir. Gerekirse, hata türlerinin bu işlevin kaybını gösterdiğinden emin olmak için geri dönün ve işlevi daha ayrıntılı bir şekilde yeniden yazın.

Her hata türü için sistem, ilgili sistemler, süreç, ilgili işlemler, ürün, hizmet, müşteri veya düzenlemelerdeki tüm sonuçları tanımlayın. Bunlar başarısızlığın potansiyel etkileridir. Bu hata nedeniyle müşteri ne yaşar? $\mathrm{Bu}$ hata oluştuğunda ne olur?

Her etkinin ne kadar ciddi olduğunu belirleyin. Şiddet derecesi S ile gösterilir. Şiddet genellikle 1'den 10'a kadar bir ölçekte derecelendirilir; burada 1 önemsizdir ve 10 felakettir. Bir hata türünün birden fazla etkisi varsa, HTEA tablosuna bu hata türü için yalnızca en yüksek önem derecesini yazın.

Her hata türü için tüm olası temel nedenleri belirleyin. Neden analizi araçları olarak sınıflandırılan araçları ve ekibin en iyi bilgi ve deneyimini kullanın. HTEA formunda her hata türü için olası tüm nedenleri listeleyin.

Her bir sebep için, oluşum ihtimalini $(\mathrm{O})$ belirleyin. $\mathrm{Bu}$ derecelendirme, kapsamınızın ömrü boyunca bu nedenle meydana gelen arıza olasılığını tahmin eder. Oluşma genellikle 1'den 10'a kadar bir ölçekte derecelendirilir, burada 1 çok düşüktür ve 10 kaçınılmazdır. HTEA tablosunda, her nedenin oluşum derecesini listeleyin.

Her neden için, geçerli işlem denetimlerini tanımlayın. Bunlar, arızaların müşteriye ulaşmasını önlemek için şu anda uyguladığınız testler, prosedürler veya mekanizmalardır. Bu kontroller, nedenin gerçekleşmesini önleyebilir, bunun gerçekleşme olasılığını azaltabilir veya neden gerçekleştikten sonra ancak müşteri etkilenmeden önce başarısızlığı algılayabilir.

Her kontrol için algılama derecelendirmesini (D) belirleyin. $\mathrm{Bu}$ derecelendirme, kontrollerin nedeni veya hata türü gerçekleştikten sonra ancak müşteri etkilenmeden önce ne kadar iyi alg1layabileceğini tahmin eder. Tespit genellikle 1 ila 10 arasında bir skalada derecelendirilir; burada 1, kontrolün sorunu tespit etmek için kesinlikle kesin olduğu ve 10 kontrolün sorunu tespit etmeyeceğinden (veya kontrol olmadığı) emin olduğu anlamına gelir. HTEA tablosunda, her neden için algılama derecelendirmesini listeleyin.

Birçok endüstri için isteğe bağlı bu hata türü; güvenliği, devlet düzenlemelerine uyumu yansıtan ve özel kontrollere ihtiyaç duyan ölçümler veya göstergeler gibi.) kritik bir özellikle ilişkili mi? Bu ilişki, etiketli bir sütuna özel kontrollere gerek olup olmadığını göstermek için evet veya hayır olarak verilir. Genellikle, kritik özellikler 9 veya 10 'luk bir şiddete ve 3'ün üzerinde oluşum ve tespit derecelerine sahiptir.

Risk önceliği sayısını veya $\mathrm{S} \times \mathrm{O} \times \mathrm{D}^{\prime}$ ye eşit olan RÖG'yi hesaplayın. Ayrıca, ciddiyeti oluşumla, $\mathrm{S} \times \mathrm{O}$ çarpımıyla çarparak kritikliği hesaplayın. Bu sayılar, olası arızaları ele alınması gereken sıraya göre sıralamak için rehberlik sağlar.

Önerilen işlemleri belirleyin. Bu eylemler, ciddiyeti veya oluşumunu azaltmak için tasarım veya süreç değişiklikleri olabilir. Algılamayı geliştirmek için ek kontroller olabilirler. Ayrica, eylemlerden ve hedef tamamlama tarihlerinden kimin sorumlu olduğunu da unutmayın. 
İşlemler tamamlandığında sonuçları ve HTEA formundaki tarihi not edin. Ayrıca, yeni S, O veya D derecelendirmelerine ve yeni RÖG'lere dikkat edin.

\section{Materyal ve Metot}

Katı düzenli depolama tesisi ve bununla beraber bu atıklardan enerji üreten bir tesisin İşçi Sağlığ 1 ve Güvenliği daha da önemli hale gelmiştir. Bu nedenle çalışmamızda bu tesisin daha sağlıklı çalışabilmesi ve burada çalışanların kazalardan korunması için HTEA yöntemi kullanılarak alınması gereken önlemlerin belirlenmesi ve çözüm önerilerinin üretilmesi amaçlanmıştır. Bingöl kent merkezinde toplanan çöplerin 17 yıl boyunca sanayi bölgesine döküldüğünü ve 2013 yılında itibaren de çöplerin düzenli çöp depolama alanına dökülmektedir.

Bingöl Belediyesi Çevre Hizmetleri Birliği tarafından yapılan düzenli çöp depolama alanı ile daha önceleri vahşi depolama ve sağlıksız yapılan çöp depolamadan düzenli depolamaya geçilmiştir. Bingöl'de günlük olarak 120 ton, aylık 3 bin 600 ton, yıllık ise 43 bin 800 ton civarında çöp depolanıyor. Şehir merkezinde kamyonlar ile toplanan çöpler düzenli depolama alanına götürülüyor.

2017 y1lında Bingöl Belediyesi, özel bir firma ile anlaşma yapılarak katı atık düzenli depolama sahasında, saha işletmesi, ön ayrıştırma, bütünleşmiş tesis, çöpten enerji üretimi ve çürütme tesisi kurulması çalışmalarını başlattı. Öncelikle katı atık depolama alanında çalışan enerji firması, çöpün üstüne toprak ile örtüyor. Çalışmalar kapsamında çöpün içerisinden gazın alınması sistemi döşenmiş, su drene kanalları yapılmış, kül stok alanı toprak örtüsü ile kaplanmış, enerji santrali kurulumu, gaz toplama balonu, gaz yıkama ünitesi, ayrıştırma üniteleri kurulum çalışmalarının tamamlanmasıyla, fermantasyon yöntemiyle elektrik enerjisi üretilmesi için bütün altyap1 hazırlanmıș durumdadır ilk etapta $1 \mathrm{MW}$ enerji üretilmesi için gerekli bütün çalışmalar tamamlanmıștır. Direk olarak 20 personel, dolaylı olarak 40 personelin çalıştığ tesisin iş ve işçi sağlığ 1 ve güvenliği açısından önemi ve önlemleri üzerine çalışmalar yapılmıştır.

$\mathrm{Bu}$ araştırmamızda HTEA yöntemiyle riskleri kabul edilebilir sınırlara çekmeye yönelik çalışmalar yapıldı. Risk analizi yaparken tehlikenin sebep olduğu kazanın sonuçları ve ihtimali dikkate alınmıştır. Bu sayede alınması gereken önlemler belirlenmiş, meydana çıkabilecek sonuçları gözlemlenmiş ve önlemler belirlenmiştir. Şekil 1'de toplam kalite sisteminde HTEA'nın yeri verilmiştir. Ayrıca bu çalışmada örnek risk değerlendirme çalışması da yapılmıştır. HTEA sahip olduğu yeni düşünce anlayışıyla hataların önlenebilmesine yönelik toplam kalite sisteminin güçlü bir yöntemidir. Şekil 2'de ise HTEA akış şeması verilmiştir.

Hata türü ve etkileri analizinde, öncelikle Birincil Risk Analizi (PRA) yöntemi kullanılarak olası riskler belirlenip HTEA yöntemiyle belirlenen olası riskler derecelendirilerek Risk Öncelik Katsayısı (RÖS) hesaplaması yapılır. RÖS yüksek olan riskten düşük olan riske doğru alınacak önlemler sırasıyla belirlenerek risk derecesi düşürülür.

P, S, D, RÖS, harfleriyle gösterilen sembollerin anlamları aşağıda verilmiştir:

-P: Her bir zarar türünün oluşma olasılık değeri;

-S: Zararın ne kadar önemli olduğunun değeri, şiddet,

-D:Zarar meydana getirecek durumun keşfedilmesinin zorluk derecelendirilmesi,

-RÖS: Risk öncelik sayısı RÖS değeri $P, S$ ve $D$ değerlerinin çarpımıyla elde edilir.

-RÖS= P (olasılık) x S (şiddet) x D (fark edilebilirlik).

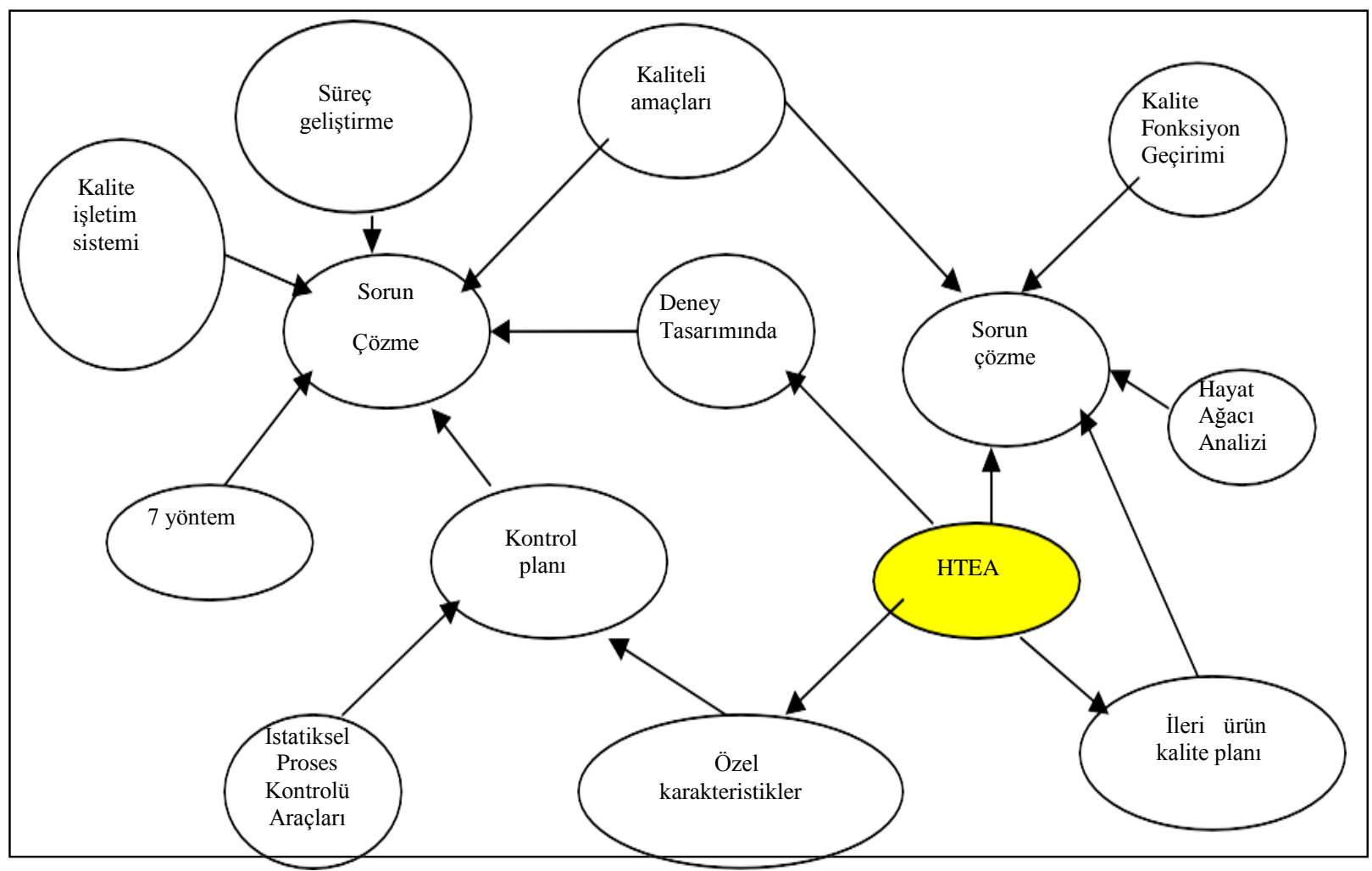

Şekil 1 Toplam kalite sisteminde HTEA'nın yeri [2] 


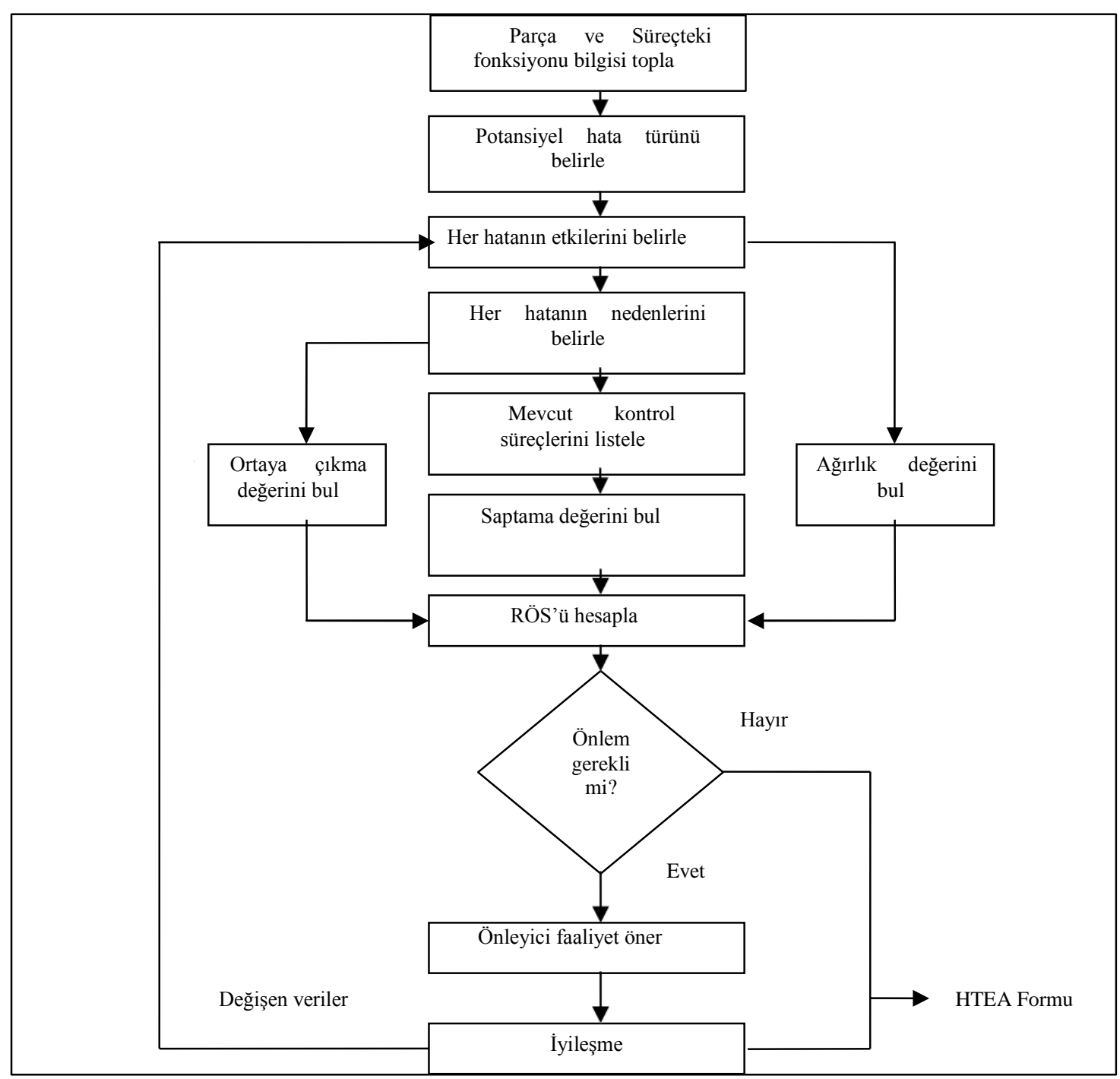

Şekil 2. HTEA akışş şeması [3]

Tablo 1'de S değeri-zararın şiddeti derecelendirme tablosu, Tablo 2'de P değeri-zararın oluşma olasılığı derecelendirme tablosu, Tablo 3'de ise D değeri-fark edilebilirlik derecelendirmeleri verilmiştir.

Olası risk yapısına göre standart değerler bu tablolardan seçilmektedir. Analizler bu önlemlere göre yapılmakta ve sonuçlar risk tablosuna kaydedilmektedir. HTEA metoduyla yapılan çalışmanın faydası; sistemdeki aksaklıklar ve sistem çalışması hakkında bilgi sağlamaktadır. Önlemlerin alınmasından sonra yeniden RÖS değerleri hesaplanarak, hesaplanan bu değerlerin kabul edilebilir seviyede olması gerekmektedir.

Tablo 1. Şiddet Derecelendirilmesi [4]

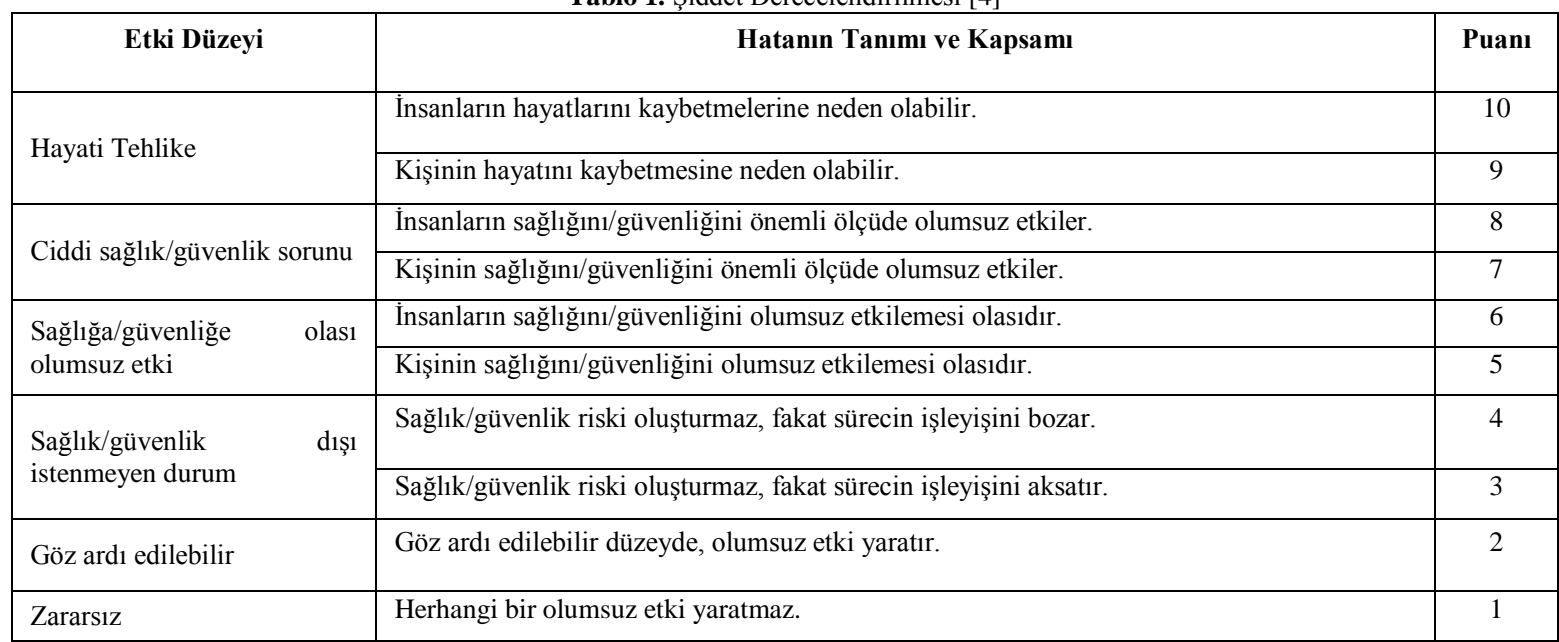


Tablo 2. Olas1lık Derecelendirilmesi [4]

\begin{tabular}{|c|c|c|}
\hline Hata Olasılığı & $\begin{array}{ll}\text { Atfedilen Sıklık } \\
\end{array}$ & Puanı \\
\hline \multirow{2}{*}{ Çok Yüksek } & Saate 1 veya daha sik & 10 \\
\hline & Günde 5-10 kez & 9 \\
\hline \multirow{2}{*}{ Yüksek } & Günde 1-2 kez & 8 \\
\hline & Haftada 3-5 kez & 7 \\
\hline \multirow{2}{*}{ Olast } & Haftada 1-2 kez & 6 \\
\hline & Ayda 1-2 kez & 5 \\
\hline \multirow{2}{*}{ Düşük } & Yilda 3-5 kez & 4 \\
\hline & Yilda 1-2 kez & 3 \\
\hline \multirow{2}{*}{ Çok düşük } & 5 yılda 1 & 2 \\
\hline & 10 yilda 1 veya daha seyrek & 1 \\
\hline
\end{tabular}

Tablo 2. Fark edilebilirlik Derecelendirilmesi [4]

\begin{tabular}{|c|l|c|}
\hline \multicolumn{2}{|c|}{ Hatanın ve/veya Nedeninin Belirlenimi } & Puanı \\
\hline $\begin{array}{c}\text { Neredeyse imkânsız } \\
\text { Yüksek/Olası }\end{array}$ & Süreçten sonra bile belirlenemeyebilir. & 10 \\
\hline Pek mümkün görünmü̈yor & Süreç sonuna kadar belirlenemez. & 9 \\
\hline Olasıllğı zayıf & Süreç sonuna kadar belirlenemeyebilir. & 8 \\
\hline Çok zor & Birkaç adım süresince belirlenemez. & 7 \\
\hline Zor & Sonraki adımın sonlarında belirlenebilir. & 6 \\
\hline Zor değğl & Sonraki adımın başlarında belirlenebilir. & 5 \\
\hline Beklenir & Sonraki adıma geçilmeden belirlenebilir. & 4 \\
\hline Kolay & Sonraki işlem sırasında belirlenir. & 3 \\
\hline Çok kolay & Sonraki işlemden önce belirlenir. & 2 \\
\hline Neredeyse kesin & Anında belirlenir. & 1 \\
\hline
\end{tabular}

En büyük RÖS değeri 1000 en düşük RÖS değeri ise 1 'dir. Kabul edilebilir RÖS sınırı; işin yapısı, çalışan tecrübeleri, bütçe, çalışılan ülkeye ait yasalar ve benzeri kriterler göz önünde bulundurulup analiz edilerek üst yönetimce onaylanıp kabul edilmektedir (TSE-14798, 2013).

Kabul edilebilir RÖS değerinin hesaplanması:

Kabul edilebilir $($ RÖS $)=$ Kabul edilebilir $(\mathrm{P}) \times$ Kabul edilebilir (S) x Kabul edilebilir (D)

Çalışmada;

-Kabul edilebilir ihtimal,arada bir hata = 1/2000 alınır; bu durumda $\mathrm{KE}(\mathrm{P})=4$,

-Kabul edilebilir şiddet, küçük şiddet = sistemin çalışmasını yavaşlatan hata alınır; bu durumda

$\mathrm{KE}(\mathrm{S})=3$,

-Kabul edilebilir keşfedilebilirlik, yüksek ortalama = potansiyel hatanın nedeninin ve takip eden hatanın keşfedilebilirliği yüksek ortalama alınır; bu durumda $\mathrm{KE}$ (D) $=4$ olur.

-Son durumda KE (RÖS) $=4$ × 3 × 4 ise,

-Kabul Edilebilir RÖS = 48 olarak hesaplanır.

RÖS değerlerine göre önlem durumları Tablo 4'de verilmiştir.

Tablo 4. RÖS (Tanık, 2019)

\begin{tabular}{|c|c|}
\hline RÖS DEĞERI & ÖNLEM \\
\hline RÖS $<48$ & Önlem almaya gerek yok. \\
\hline $48 \leq$ RÖS $\leq 100$ & Önlem alınabilir. \\
\hline RÖS $>100$ & Önlem alınması gereklidir. \\
\hline
\end{tabular}

\section{Bulgular ve Tartışma}

Belirlenen risk ve tehlikelerin tümüne ait değerlendirmeler Tablo 5'de verilen şablon kullanılarak yapılmıştır. Bu değerlendirmeler aşağıda 21 madde halinde sunulmuştur.

1- İşçilerin aşırı sıcak havada çalışma tehlikesi sıcak çarpması sonucu yaralanma veya ölümlerine sebebiyet verebilmesinin RÖS değeri 105 olarak hesaplanmıştır Rös Değerinin düşürülmesi için çalışanlar aşırı sıcak havada çalışırken sık dinlenme molaları vermeleri ve bol sıvı tüketmeleri sağlanmış olup sonuçta 5 olan olasılık katsayısının 1'e düşmesine dolayısıyla RÖS değerinin 21 olarak hesaplanmasını sağladığından sadece bu önlemin sıcak çarpmasına karşın \% 80 başarı sağladığı görülmüştür. 2- Tesiste acil kapatma vanasının olmaması veya çalışır durumda olmaması tehlikesi patlama, veya yangın çıkmasına sebebiyet verebilmesinin Rös değeri 112 olarak hesaplanmasına sebep olmuştur. Ancak tankların periyodik muayeneleri sırasında acil kapatma vanasının çalışır durumda olduğu kontrol edilmesiyle, çalışmayan vanalar ivedilikle değiştirilmesine, çalışır duruma getirilmesine, tank sorumlusuna acil durumlar ile ilgili bilgi ve talimat verilmesiyle, tank alanı içerisinde kullanıma hazır yangın tüpleri bulundurulmasıyla, çalışanlara acil durumlar ile ilgili eğitim verilmesi ve tatbikatlar yapılması sağlanmış olup sonucta 4 olan olasılık katsayısının 1'e düşmesine dolayısıyla Rös değerinin 28 olarak hesaplanmasını 
sağlayacağından sadece bu önlemin yangın veya patlama ihtimalini \% 75 azaltmasını sağladığ 1 görülmüștür.

3- Tesiste deprem sensörünün olmaması tehlikesi gaz kaçağı, sızıntı, patlama, yangın çıkmasına sebebiyet verilmesinin rös değeri 105 olarak hesaplanmasına karşın, deprem ile oluşan yer sarsıntılarında olabilecek gaz kaçağı, yangın, patlama $\mathrm{vb}$ tehlikeleri ortadan kaldırmak için lng tankları üzerinde deprem sensörü olması sağlandığından 7 olan kaza olasılığının 1 düşmesiyle bu sebebden dolayı çıkabilecek patlama veya yangınlara karşı \% 85 dolayında başarı sağladığ1 görülmüştür.

4- Tesisteki genel dağıtım pano kapağının kilitli olmaması tehlikesi yetkisiz kişilerin müdahalesi sonucu elektrik kaçağı, elektrik çarpması, yangın çıkmasına sebebiyet verebilmesinin RÖS değerinin 84 olarak hesaplanmasina sebep olmuştur. Ancak genel dağıtım panosunun kapağ sürekli kapalı tutulmasıyla, genel dağıtım pano üzerine gerekli uyarı levhaları asılmasıyla, yetkili elektrik personeli dışında genel dağıtım panosuna kimsenin müdahale etmemesi sağlanmasıyla, genel dağıtım panosu ve trafonun etrafı çevrilmesiyle, bu alana yangın tüpleri ve her türlü uyarı levhaları asılmasıyla çıkabilecek yangın karşı önemle alındığından olasılık 3'den 1'e düşmesini sağladığından RÖS değeri 28 olarak hesaplanmakta riskin önlenmesi \% 67 oranında başarı sağladığı görülmüştür.

5- Tesisteki pano kapaklarının kilitli olmaması tehlikesi yetkisiz kişilerin müdahalesi sonucu elektrik kaçağı, elektrik çarpması, yangın çıkmasına sebebiyet verebilmesinin RÖS değerinin 105 olarak sebep olmuştur. Ancak tesis içerisinde kullanılan elektrik panolarının kapakları her zaman kapalı tutulmasıyla, yetkisiz kişilerin elektrik panolarına ulaşımı engellenmesiyle, panolar üzerine yetkili elektrik personelinin iletişi bilgileri ile gerekli uyarı levhaları asılmasıyla asıldığından çıkabilecek yangın olasılığı 5'den 1'e düştüğü dolayısıyla RÖS değeri 21 olarak hesaplandığından riskin önlenmesi \% 67 oranında başarı sağladığı görülmüştür.
6- Tesiste acil durum toplanma merkezinin belirlenmemiş olması bir tehlike arz etmektedir ve bu tehlike acil durumda kargaşa çıkmasına, personele ulaşılamamasına sebebiyet verebilmesinin RÖS değeri 112 olarak hesaplanmasına vermiştir. Ancak işyeri içerisinde tüm çalışanların kolayca ulaşabilecekleri güvenli bir bölge acil durum toplanma merkezi olarak belirlenmesi, acil durum toplanma merkezinin yeri, acil durum krokisi üzerinde tüm çalışanlara ilan edilmesi, çalışanlara acil durumlar ile ilgili bilgi ve eğitim verilmesiyle kaza çıkabilme olasılık katsayısı 4'den 1 düştüğünden riskin önlenmesi \% 75 oranında başarı sağladığı görülmüştür.

7- Tesiste elektrik çarpması ölümcül tehlike arz etmekte ve RÖS değeri 105 olarak hesaplanmaktadır, Ancak gerekli önlem olarak tespit edilen jeneratör kapısı açık tutulmamalı, kilitli olmalı. Yetkili elektrikçiden başkası jeneratöre müdahale etmemeli, anahtarlar yetkili kişide bulunmalı. Jeneratör çevresinde uyarı/ikaz işaret ve levhaları bulundurulmalı. Jeneratör gövde topraklaması yapılmalı, yılda bir kez topraklama ölçümleri yapılmalı, jeneratör için ayrı bir elektrik tesisatı kurulmalı. Jeneratörün periyodik bakımları yapılmalı, bakım kartları/defteri oluşturulmalı. Kutup değiştirici şalterler kullanılmalı. Kablo yalıtımları uygun olmalı, jeneratör önünde yalıtımlı paspas yapılması ile olasılık katsayısı 7'den 1'e düşeceğinden ölümcül kazanın önlenmesinden \% 86 kat başarı sağlanmış olduğu görülmüştür.

8- Parlama, alev alma tehlikesi yangın çıkmasına sebebiyet verebilmesinin RÖS değeri 84 olarak hesaplanmasına karşın, jeneratörün periyodik bakımları yapılmalı, bakım kartları oluşturulmalı. Yanıcı, yakıcı cisim ve malzemelerle yakıt tankının yanına yaklaşılmamalı, uyarıcı ve yasaklayıcı işaret ve levhalar jeneratör çevresine yerleştirilmeli. Yetkili elektrikçiden başkası jeneratöre müdahale etmemesiyle yangın çıkabilme olasılığın 3'den 1'e düşmesiyle RÖS değeri 28 olarak hesaplandığından riskin önlenmesi \% 86 oranında başarı sağladığı görülmüştür.

Tablo 5.Katı atık düzenli depolama tesisleri ile ilgili örnek risk analizi çalışması [5]

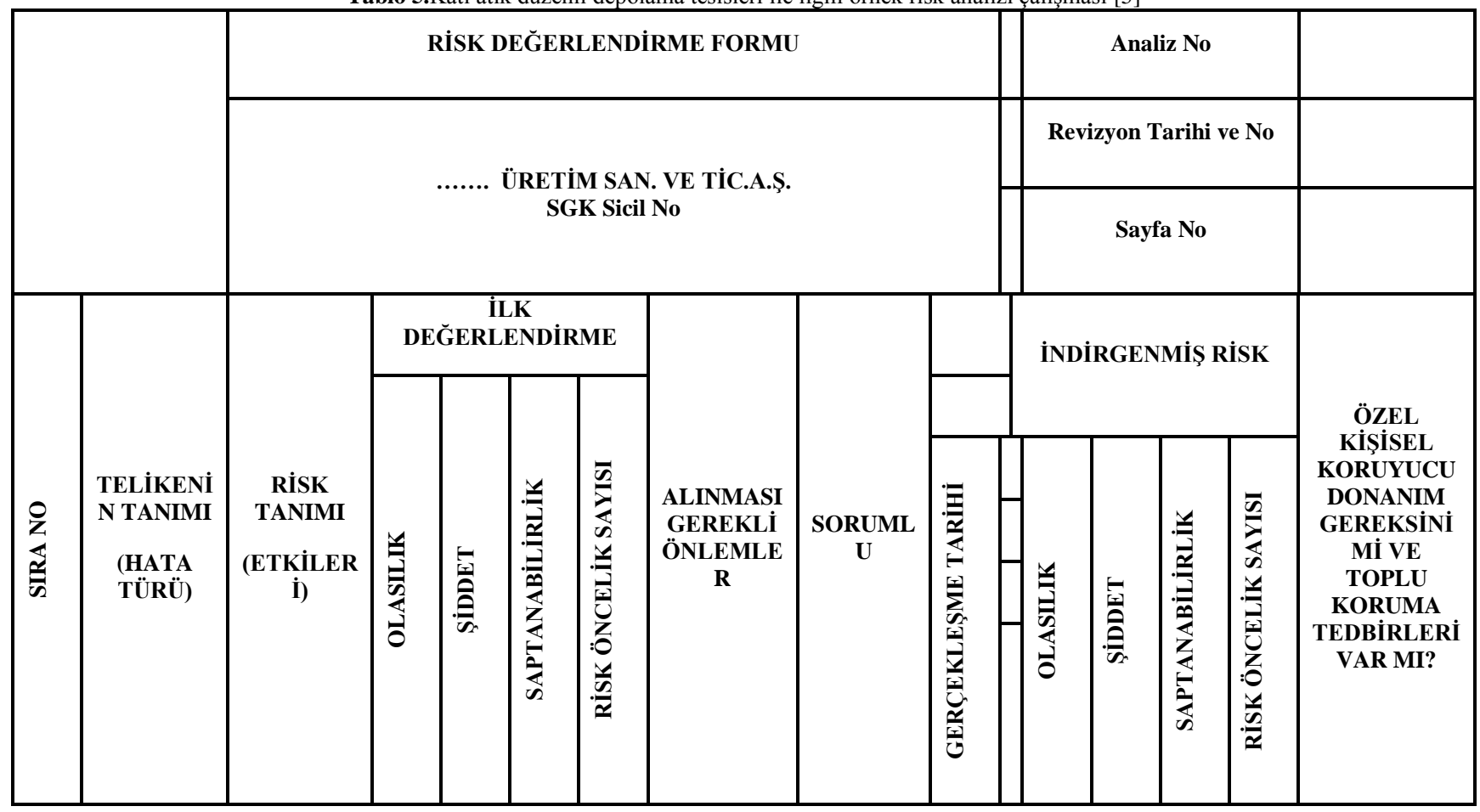


9-Elektrik çarpması tehlikesi ölümcül bir kazaya sebebiyet verebilmesinin RÖS değeri 105 olarak hesaplanmasina karşın, kırıcı-delici nitelikli el aletleri yağmur altında veya nemli ortamda birakılmamasiyla, cihaz kuru ve temiz tutulmasiyla, topraklı prizler kullanılmasıyla, seyyar panolarda 30ma'lik kaçak akım rölesi bulunmasıyla, elektrik bağlantı elemanları korunmasıyla, kabloda koruyucu olmasıyla. Enerji kablosuna ikinci yalıtım koruması yapılmasıyla, fiş prize takılı iken ayar ve bakım yapılmamasıyla, çalışma esnasında şebeke ve uzatma kablosu her zaman cihazın arka tarafında bırakılmasıyla, çalışmaya başlamadan önce çalışma alanında üzeri kaplanmış olan elektrik hatları kontrol edilmesiyle, kırık fiș ve prizler kullanılmamasıyla önlemler alınması gerekir. Ancak bunlardan herhangi hepsinin ve herhangi birisinin olması ile uygun iş ayakkabısı ve baret kullanılmasıyla ölümcül kazanın çıkabilmesinin 5 olan olasılık katsayısının 1 'e düşmesine dolayısıyla RÖS değerinin 21 olarak hesaplanmasını sağladığından bu önlemle ile \% 80 başarı sağlanmaktadır.

10- Çalışmaya uygun kkd kullanılmaması tehlikesi yaralanma veya ölüme sebebiyet verebilmesinin RÖS değeri 112 olarak hesaplanmasına karşın, çalışanların yaptıkları işe uygun iş ayakkabısı giymeleri sağlanmasıyla. Ayrıca çalışma alanında baret, iş gözlüğü, eldiven, reflektörlü yelek kullanmaları sağlanmasıyla ölümcül olabilecek kaza olasılığ 1 4'den 1 düştüğünden RÖS değeri 28 olarak hesaplanmasını sağlayacağından önlem \% 75 oranında başarı sağladığı görülmüştür.

11-Tesiste yangın söndürücü cihaz bulunmaması tehlikesi yangına müdahale edememe kaynaklı yaralanma veya ölüm olayına sebebiyet verebilmesinin RÖS değeri 105 olarak hesaplanmasına karşın, çalışma alanı içerisinde el aletlerinin ve diğer ekipmanların taşındığı araçta seyyar yangın söndürme cihazı bulundurulmasıyla. Yangın söndürme cihazının her zaman kullanıma hazır olması sağlanmalı, çalışanlara yangın eğitimi verilmeli ve tatbikat yapılmasıyla ölümcül kazanın çıkabilmesinin 7 olan olasılık katsayısı 1'e düştüğünden RÖS değeri 15 olarak hesaplanmasını meydana getirdiği ve yangın çıkması halinde anında müdahale ile \% 85 dolayında başarı sağladığı görülmüştür.

12- İş makinelerinde yangın tüpü bulunmaması tehlikesi yangına müdahale edememe kaynaklı yaralanma veya ölüm olayına sebebiyet verebilmesinin RÖS değeri 84 olarak hesaplanmasına karşın, iş makinelerinde operatörün kolayca ulaşabileceği yerde yangın tüpü bulunmasıyla ölümcül yangının çıkabilmesinin olasılığı 3'den 1 düştüğü, RÖS değeri 28 olarak hesaplanmasıyla \% 67'lik başarı sağladığı görülmüştür.

13- Tesis sahasında kamyonla çalışma tehlikesi yaralanma veya ölümlü kazaya sebebiyet verebilmesinin RÖS değeri 105 olarak hesaplanmasına sebep olmuştur. Ancak kazı işleri sırasında ekskavatör ile birlikte çalışan kamyon trafikten tecrit edilmeli, şoföre yapılan iş ve uyulması gerekli kurallar ile ilgili bilgi verilmeli, şoförün araçtan inmesi engellenmelisiyle kazanın olma olasılığg 5 'den 1'e düştüğü, RÖS değeri 21 olarak hesaplanmasıyla kamyon çalışmasından kaynaklı kazaların \% 80 önüne geçildiğ görülmüştür.

14- Tesisteki iş makinelerinin operatör belgesi olmayan personelin makineyi kullanması tehlikesi makinelerin devrilmesine sebebiyet verebilmesinin RÖS değeri 112 olarak hesaplanmasina sebep olmuştur. Ancak iş makinelerini kullanan personelin operatörlük belgesi olmalı, operatörlük belgesi olmayan personelin makineleri kullanması engellenmesiyle kazanın olma olasılığ1 4'den 1'e düştüğü, RÖS değeri 28 olarak hesaplandiğından makinelerin devrilmesi kaynaklı kazalarda \% 75 başarı sağladığı görülmüştür.

15- Tesiste ilkyardım personelinin bulunmaması tehlikesi ciddi sonuçlara zaman, ve müdahale açısından gecikmelerden kaynaklı sebebiyet verebilmesinin RÖS değeri 105 olarak hesaplanmasına karşın, çalışanlar arasında her 10 kişiden 1 kişi belirlenerek ilkyardım eğitimi ve ilkyardımcı sertifikası alması sağlandığ 1 dolayısıyla olasılık oranında \% 80'lik azalma aynı oranda başarı sağlandığ 1 görülmektedir.

16- Tesiste istiflenen demirlerin kayması tehlikesi yaralanmalara sebep olabilmesinin RÖS değeri 105 olarak hesaplanmasına rağmen, kullanılacak demirler belirlenen alanlarda istiflenmesiyle, uygun istif yüksekliği aşılmamasıyla, istiflerin önüne takozlar yerleştirilmesiyle yaralanmaya sebebiyet verebilecek kazaların olasılığı 7'den 1 düştüğü kazanın meydana gelmesinde \% 86 kat önlem alınmasını sağladığı görülmektedir.

17- Tesiste zehirli böcek ve sürüngenler tehlikesi yaralanma ve zehirlenmeye sebep olabilmesinin RÖS değeri 84 olarak hesaplanmasına sebep olmuștur. Ancak çalışma alanı her gün kontrol edilmeli, böcek, sürüngen vb. canlıların olup olmadığı tespit edilmesiyle, böcek sokması gibi durumlarda personel acilen en yakın sağlık kuruluşuna ulaştırılmasıyla zehirlenmelerin önüne geçilmesi olasılığı $2 / 3$ oranında azaldığ 1 dolayısıyla bu önlem \% 67 başarı sağladığ1 görülmektedir.

18- Tesise üçüncü şahısların sahaya izinsiz girişi tehlikesi is kazası, yaralanma, ölüm olayına sebebiyet verebilmesinin RÖS değeri 105 olarak hesaplanmasına sebep olmuştur. Ancak çalışmalar sırasında çalışma alanı tespit edilmeli, alanın etrafı emniyet şeridi, duba, desinatör vb. araçlarla çevrilmeli, çalışma alanına yabancı araç ve şahısların girmesine engel olunmalı, gerekli uyarı levhaları yerleştirilmesiyle ölümcül olabilecek kazalardaki olasılık oran1 5'den 1 düştüğünden \% 80 dolayında başarılı bir önlem sağladığı görülmüştür.

19- Tesiste ortamda kablo vb. malzemelerin bulunmasi tehlikesi elektrik çarpması, yaralanma, ölümlere sebebiyet verebilmesinin RÖS değeri 84 olarak hesaplanmasina sebep olmuştur. Ancak kazı işlerinin yapılacağı noktalarda elektrik kabloları, su boruları vb. ekipmanlar varsa önceden belirlenerek çalışma ortamından uzaklaştırılmasıyla, kazı işlerinden önce varsa ortamdaki elektrik, su vb. hatların kaynağının kapatılması için ilgili kurum ve kuruluşlara müracaat edilerek gerekli izinler alınmasıyla ölümcül sonuçlara varabilecek kazaların olasılığ1 3'den 1 düştüğünden önlem alınması \% 86 oranında başarı sağladığı görülmüştür.

20- İş makinelerinde gürültüye maruz kalma tehlikesi meslek hastalığına sebebiyet vereceğinden RÖS değeri 105 olarak hesaplanmasına sebep olmuştur. Ancak iş makinesi üzerine makine çalışması sırasında oluşan gürültü düzeyi yazılmalı, operatör iş makinesi kullanımı sırasında kulaklık kullanmasıyla illerde ciddi sağlık sorunlarına verebilecek meslek hastalığına yakalanma olasılığı 5'den 1 düştüğünden önlem alınması $\% 80$ başarı sağladığı görülmüştür. 
21- Tesiste haberleşme eksikliği tehlikesi acil durumlarda müdahale edememe sorununa sebebiyet vereceğinden RÖS değeri 112 olarak hesaplanmasına sebep olmuştur. Ancak çalışanlar arasında telsiz, telefon vb. haberleşme araçları kullanılarak acil durumlarda toplanmanın, müdahale etmenin, ilgili kurum ve kuruluşlara haber vermenin kolaylaştırılması sağlanmasıyla olasılık oranında 4'den 1'e düşüş sonucu önlem alınması acil durumlarda sağlık sorunlarının önüne geçmek adına \% 75 başarı sağlayacaktır.

Ülkemizin sosyal ekonomik ve kültürel yönleriyle toplumun refah seviyesini önemli ölçüde etkileyeceği belirgindir. Çevre ve sağlık konularında ekolojik dengeye duyarlı yaklaşımlar esas olmaktadır. Ekolojin dengesinin korunmasında katı atıkların çevreye zarar vermesinin önlenmesi ve bu bilincin oluşması gelecek nesillerin sağlıklı bir doğada yetişmesini de önemli kılmaktadır.

Risk değerlendirmesiyle sunulan risklerin, iş hayatındaki İş Sağlığı ve Güvenliği algısına göre orijinlerinde bertaraf edilmelidir ya da etkileri indirgenmelidir. $\mathrm{Bu}$ çalışmayla katı halindeki atık depolama işletmelerinde çalışanları kapsayan oldukça fazla risk ve tehlike varlığ 1 görülmektedir. Maalesef ki bu konuyla ilgili önemli çalışmalar sunulsa da yetersizlik hala mevcuttur.

$\mathrm{Bu}$ çalışmada elde edilen risk değerlendirme sonuçlarına göre, atık riskleri yüksek olan katı atık depolama tesislerinin kapasitelerini göz önünde bulundurarak atık yönetim şekillerini tekrar düzenlemesi gerektiğini göstermektedir. Atıkların geçici olarak depolandığı alanlarda gerekli şartları sağlayarak, çevreye etkisi en aza indirilmelidir. Bu çalışma tesis yöneticilerine atık risklerinin azaltılması konusunda yol gösterici olacaktır.Genel tesis bazında yapılan değerlendirmelerin yanı sıra, atık yönetiminde başarısızlığa neden olan faktörleri belirlemeli ve atık yönetimindeki etkinliklerini arttırmalıdır.Başarılı olan katı atık depolama tesisleri ise bu durumlarını devam ettirebilmek için eğitim ve bilinçlendirme çalışmalarına aksatmadan devam etmeleri sağlanmalıdır.

$\mathrm{Bu}$ araştırmadan çıkan bulgular tekrarlanan geçmişteki veriler irdelenerek hem muhtemel olabilecek kazalar ile alakalı risk durumları için çözüm üretmek ve beklenmeyen kazaların veya riskler belirlenmiş ve engellenmiştir. Risk değerlendirmesi sonuncunda bazı faaliyetlerle ilgili daha önceden gerekli önlemler alındığı tespit edilmiş, bazılarında ise risk değerlendirmesi sonrasında gerekli düzenleyici önleyici faaliyetler yapılmıştır. Risk değerlendirme sonucu derlenecek olursa; tesiste çalışanlara depolama sirasında yapilan faaliyetlerle ile ilgili karşılaşılabilecek tüm tehlike ve risklere karşın mutlaka eğitim verilmesi gerekliliği ortaya çıkmıştır. Hayati önemdeki acil ve dikkat gerektiren basit eğitimlerin sürekli olarak her gün işe başlamadan önce, farkındalık ve güvenlik kültürünün oluşturulması noktasında çalışanlara büyük katkı sağlayacaktır.

Yapılan bu çalışmada risk değerlendirmesi sonucu olarak, atık depolama yönetiminde başarıya ulaşılması için öncelikle konunun öneminin farkına varılması gereklidir. Atıkların gözden çıkarılan maddeler olarak görülmemesi, yeniden kullanılabilir kaynaklar olarak görülmesi bunun ilk adımıdır. Atıkların kaynağında ayrı olarak toplanmasında başarıya ulaşmak için atık üreticilerinin uygulamayı benimsemeleri ve konuya zaman ayırmaları gerekmektedir. Atıkların ayrı olarak toplaması, bir angarya değil, bir görev olarak görülmelidir. Bireysel olarak uygulamanın kendilerine bir yarar sağlamayacağı, ulusal anlamda büyük bir kaynak tasarrufu sağlanacağı görüşü benimsenmelidir.

Yapılan bu çalışmada çevresel etkileri üzerine de önemli sonuçlar doğurmuştur. Katı atık düzenli depolama alanlarında sistematik, düzenli ve güvenlikli çalışmalar işlerin aksamasının önüne geçildiği, araç ekipman konusunda aksama göstermediğinden çevresel oluşabilecek sorunların ortadan kaldırılmasına sebep olacağı düşünülmektedir. Ayrıca sistemin bir devamı olan şehirlerden çöp toplanması da birebir bağlantılı bir süreç olduğundan çöp toplanmasına düzenli depolama tesisinde oluşabilecek bir neden olabilecek bir sorunun önüne geçileceği düşünülmektedir.

Son olarak daha önceki araştırma sonuçlarına paralel olan bu sonuçlar, atık yönetiminin disiplinler arası bir çalışma ve uygulamaya yönelik olduğunu ve tüm birimlerin koordineli çalışmaları ve işbirliği içinde olması gerektiğini göstermektedir. Çevre bilincinin oluşması, atık yönetiminin temel ilkesi olan geri dönüşümün yaygınlaşması için gerekli olan ilk şarttır. Belediyelerin de bu farkındalığı yaratmak için önemli görevleri var. Sivil toplum kuruluşlarının yardımıyla yapılacak çalışmalar yönetime katılımı artırarak atıkların toplanması ve ayrılması gibi konularda farkındalık seviyesini artıracaktır. Ayrıca kaynakların etkin kullanımı ve sürdürülebilir çevre anlayışı geliştirilecektir.

\section{Açıklamalar}

Bu çalışmada etik kurul onay belgesine gerek yoktur.

\section{Kaynaklar .}

[1] Tekinşen, O.C., 1989.İşçi Sağlığı ve İş Güvenliği Paneli Açılış Konuşması, Çalışma ve Sosyal Güvenlik Bakanlığı, İşçi Sağlığı Daire Başkanlığı, İşçi Sağlığı ve İş Güvenliği Sempozyumu, Ankara 1989. 11-13s.

[2] Yilmaz, B.S., 2000. Hata Türü ve Etki Analizi, Dokuz Eylül Üniversitesi SBE Dergisi, 2(4): 137.

[3] Bayraktar O.M., 2009. Hata Türleri ve Etkileri Analizi (HTEA) ve Taguchi Metodu'nun Bonfiglioli A.Ş.'de Ortak Uygulaması, Yüksek Lisans Tezi, Gazi Üniversitesi, Ankara.

[4] Tanık, M., 2019. Hata Modu ve Etkileri Analizi. kisi.deu.edu.tr//murat.tanik/fmea.pdf, 13 Haziran 2019.

[5] Baki, M. S., 2020. Katı Atık Düzenli Depolama Tesislerinde Hata Türü Etkileri Analizi Yöntemiyle İş Sağlığı ve Güvenliği Açısından Risk Analizi-Bingöl Örneği, Yüksek Lisans Tezi, Munzur Üniversitesi, Tunceli. 